\title{
Assessment of the working environment risks for the workers of electrical engineering industry
}

\author{
Larysa Tretiakova \\ Department of occupational safety \\ National Technical University of \\ Ukraine "Igor Sikorsky Kyiv \\ Polytechnic Institute" \\ Kyiv, Ukraine \\ 1t79@ukr.net
}

\author{
Elina Rebuel \\ IE Business School \\ Madrid, Spain \\ etretiakova@gmail.com \\ elit.yver@gmail.com
}

\author{
Vitalii Opryshko \\ Department of power supply \\ National Technical University of \\ Ukraine \\ «Igor Sikorsky Kyiv Polytechnic \\ Institute» \\ Kyiv, Ukraine \\ livestrongtm@gmail.com
}

\begin{abstract}
While performing work in modern electrical installations, electrical technicians are faced with adverse events that can cause threats to their life. We analyze in this article the safety requirements for setting up live and near-current electrical installations, which are set out in national standards and EU Directive 2004/40 According to the study of working conditions, the most dangerous factors that can affect the health of workers are: electric shock; the electromagnetic field emission; getting under the induced voltage and step voltage; the impact of acoustic noise and the work at height in uncomfortable working positions. The method of calculation of individual risks during the regular work is offered, which gives an opportunity to further determine the effectiveness of the security measures implementation.
\end{abstract}

Keywords - electrical workers; electromagnetic field, regulatory values, safety measures; individual risk.

\section{INTRODUCTION}

While implementing work in existing electrical installations, electrical technicians are faced with unpredictable risks that can put their life in danger and be hazardous for their health. Measures to protect the health of employees are a mandatory component when working in electrical installations. Performing the job near electrical installations can lead to electric shocks in the situation of the direct contact with live parts; an electromagnetic field emission (hereinafter - EMF) caused by industrial frequency; hit by induced voltage that occurs in emergency modes or switches in communications networks, low-voltage power lines and metal structures located near existing electrical installations; getting under the action of the step voltage on the soil surface; exposure to acoustic noise from transformers, wind power plants and overhead lines; performing work at height in uncomfortable working positions.

Another category of people who are exposed to hazards is the population living close to operating outdoor electrical installations. Every year, up to fifty outsiders are recorded as dying in hazardous areas in the close proximity of active electrical installations. The other type of hazard is created by EMFs in the areas located near overhead lines, which are built near settlements and the areas served the agricultural needs. People who live in the areas affected by electrical networks for a long time, might not be aware of the danger.
The analysis of the statistics of the accidents occurring at the energy complex enterprises confirms the high level of injury among electrical workers. In 2018, there were 85 accidents involving 87 employees, seven of which were fatal. In 2017, 65 accidents were reported, resulting in 77 workers being injured, nine of which were fatal [1]. The causes of the accidents are the following: the touch of live parts of the electrical installations (up to 62\%), getting under the induced voltage $(15 \%)$, the disregard of the health and safety instructions (12\%), falling from a height and getting under the road transport while performing work $(8 \%)$ and getting under the step voltage $(3 \%)$. The influence of industrial frequency EMFs and acoustic noise from electrical installations leads to various health damage (certain diseases) among electricians and outsiders. $76 \%$ of incidents occur as a result of erroneous actions by employees.

Obviously, the result of this analysis should, in addition to the identification of the reasons themselves, target the ways to eliminate them as well as prevent the reoccurrence of the injuries, so to serve as the preventive component of the health and safety measures.

The main document was indicated that the main direction of improving occupational safety is planned systemic actions, which lead to a reduction in the level of risks [2]

The Directives and International Standards recommended for implementation [3, 4, 8] to build a safety management system in four stages: perform the risk assessment; planning; realization and control. In the article, employee safety is defined as the level of protection at which the risk of the physical, biological, social or material loss does not exceed the acceptable value defined by expert institutions. These standards emphasizes that safety in the field of products and processes standardization is implemented to reduce the health and the environmental risks to the approved levels.

Directive 2004/40 introduced the health and safety requirements for both groups (workers and the general population) in the case of risks from the effects of electrical installations. The main part outlines the requirements for protection against the existing risks in EMF: the choice of electrical equipment and protection systems; the list and designs of personal protective equipment; means of controlling the level of radiation; ways of training electrotechnical workers. The annexes contain normative values of 
allowable levels of electric and magnetic fields, taking into account frequency, current density, and duration of the exposure. It was found that there were some differences between the provisions of the directive and national law. The directive differentiates the allowable values of the electric field strength for individual areas of the human body (table 1)

TABLE I THE PROBABILITY OF EVENTS AND CONSEQUENCES ARISING FROM ACCIDENTS

\begin{tabular}{|c|c|c|c|}
\hline $\begin{array}{l}\text { Type of } \\
\text { limitation }\end{array}$ & $\begin{array}{l}\text { Type of } \\
\text { influencing } \\
\text { factor }\end{array}$ & Human organs & $\begin{array}{l}\text { Permissible } \\
\text { value }\end{array}$ \\
\hline \multirow{8}{*}{$\begin{array}{l}\text { Basic } \\
\text { level of } \\
\text { influence }\end{array}$} & \multirow{3}{*}{$\begin{array}{l}\text { EF } \\
\text { intensity, } \\
\mathrm{kV} / \mathrm{m}\end{array}$} & Brain & 0.0531 \\
\hline & & $\begin{array}{l}\text { Heart and other } \\
\text { internal organs }\end{array}$ & 0.943 \\
\hline & & $\begin{array}{l}\text { Palm, wrist, leg, } \\
\text { knee }\end{array}$ & 2100 \\
\hline & \multirow{3}{*}{$\begin{array}{l}\text { Current } \\
\text { touch, } \mathrm{mA}\end{array}$} & Footstep & 3.0 \\
\hline & & $\begin{array}{l}\text { Contact by hand } \\
\text { (grab) }\end{array}$ & 3.0 \\
\hline & & $\begin{array}{l}\text { Contact by hand } \\
\text { (touch) }\end{array}$ & 1.5 \\
\hline & \multirow{2}{*}{$\begin{array}{l}\text { MF } \\
\text { intensity, } \\
\mathrm{A} / \mathrm{m}\end{array}$} & $\begin{array}{l}\text { Whole body for } 8 \\
\text { hours }\end{array}$ & 400 \\
\hline & & $\begin{array}{l}\text { Whole body for } 2 \\
\text { hours per working } \\
\text { shift }\end{array}$ & 4000 \\
\hline \multirow[t]{3}{*}{$\begin{array}{l}\text { Maximum } \\
\text { permissibl } \\
\text { e level }\end{array}$} & $\begin{array}{l}\mathrm{EF} \\
\text { intensity, } \\
\mathrm{kV} / \mathrm{m}\end{array}$ & $\begin{array}{l}\text { On average, all over } \\
\text { the body }\end{array}$ & 20 \\
\hline & \multirow{2}{*}{$\begin{array}{l}\text { MF } \\
\text { intensity, } \\
\mathrm{A} / \mathrm{m}\end{array}$} & Head, torso & 2170 \\
\hline & & Hands, legs & 5000 \\
\hline
\end{tabular}

Allowable values of magnetic field strength are established, the possible negative effects of EMF on longterm health of workers are considered.

\section{DESCRIPTION OF MATERIAL AND RESEARCH METHODS}

Full implementation of the European security concept is possible within the framework of a multifactor model "Electrical installation - complex of hazardous industrial factors - employee - safety measures". Within the framework of this model, ergodic optimal management provides for a mathematical assessment of the impact of environmental factors on the life and health of employees.

The solution to the problem of reducing the levels of injuries in electrical installations is based on the risk-oriented method. Employers, in accordance with the Directive, are required to ensure that working conditions are taking into account the new scientific data on the risks of exposure to EMFs aiming to improve worker safety and occupational health. As the experience of the authors shows, it offers the opportunity to propose a comprehensive approach while choosing technical and organizational measures and therefore developing new personal protective equipment for safe interaction between employees and electrical installations at different hierarchical levels. Nowadays, there are certain discrepancies on the level of the different normative documents, departmental regulations, requirements on application of risk-oriented methods and methodical support of such methods [5]. Before that the concept of "occupational risk" for electricians had different interpretation and content, and the used indicators were not comparable. There was no connection between the risk of injury performing the routine or emergency works in electric installations of high voltage and the normalized indicators, which were accepted to characterize dangerous and harmful factors at the workplace. Therefore, the development of the methodological concept for assessing occupational risk, taking into account the particularities of performing work in electrical installations is an urgent task.

The purpose of the article is to evaluate the production risks for electrical technicians who perform the work under voltage and near operating electrical installations. It also based on a complex analysis of working conditions, indicators of electric and magnetic fields, current density and comparison with normative indicators.

Analytical processing of statistical information on working conditions in existing electrical installations shows that now more than $22 \%$ of electrical workers work under the influence of at least one harmful factor, 30\% - under the influence of two or more harmful factors, and the working conditions in the workplace do not meet the hygiene standards for $65 \%$. * The main harmful factors are: adverse weather conditions (too high or too low temperatures); work with hazardous chemicals (acids, alkalis, petroleum products), strong electric and magnetic fields. Strong EMF sources are switchgears, transformer substations, $110-750 \mathrm{kV}$ overhead power lines.

Improving the safety of electro-technical workers is a difficult task because of the simultaneous impact of a number of harmful factors. Regardless of the type of work, the following types of actions can be distinguished: preparation for the job; workers delivery to height; execution of the job, on connection of protective means direct execution of the job. The following measures are foreseen in preparation for the job: the definition of the climatic conditions; the measurement of normalized indicators (EMF intensity, current, potential distribution, isolation level); the preparation of the work site; the inspection of instruments and tools, the preparation of the employee for work. Workers wear protective equipment that consists of protective clothing, helmets, gloves, shoes and an insurance belt. Work in open electrical installations occurs at an altitude of two to sixteen meters. One of the dangerous stages is the lifting of workers up. Telescopic towers, stairs made of duralumin tubes, or suspended cabins are used to do this. After lifting the support, the worker must be at a safe distance from the wires because of the possibility of remote injury. The safe distance is determined by the voltage level and ranges from one to five meters. Workers on the ground should not approach the overhead line closer than $(8 \ldots 10) \mathrm{m}$. This requirement is conditioned by the possibility of step voltage, as well as getting into the range of EMF. Works performed at altitude are associated with high levels of physical and intellectual activity. The installer during the production operations $60 \%$ of working time is in the "stand, stand 
straight" position and up to $40 \%$ in the "bending" position, the duration of concentrated observation - up to $90 \%$. The studies of the structure of injury on topographic areas of the body of installers showed that the most injured are: fingers $40 \%$; lower leg - 18\%; head - 5\%; spine - 3\%.

\section{RESULTS}

The risk-based method allows the assessment of the complex impact of harmful factors and the possibility of the occurrence of an adverse event.

Risk is an additive function, so in a multiplicative form that makes it possible to evaluate the simultaneous impact of $M$ factors, we write:

$$
R=\left\{\sum_{i=1}^{M}\left(S_{f i}, P_{d i}, D_{f d i}\right)\right\},
$$

where $R$ is the general individual risk; $S_{f i}$ - conditions of occurrence of the $f$-th adverse event; $P_{d i}$ is the probability that the $d$-th accident will happen; $D_{f d i}$ - the possible consequences of a $d$-accident, which will occur in the $f$-th adverse event.

Individual risk $R_{i}$ under (1) condition can be given as [6]

$$
R_{i}=P_{f} \cdot P_{d / f}
$$

where $\mathrm{P}_{f}$ is the probability of occurrence of $f$-th adverse event; $P_{d f f}$ - the possibility of an employee having consequences from a given adverse event in the presence of measures and safeguards.

The probability of a $\mathrm{P}_{f}$ adverse event, which can lead to an accident, can be given as a product of probabilities - the emergence of danger $P(A)$ and the impact of this danger on employee $P(B)$ :

$$
P_{f}=P(A) \cdot P(B) .
$$

Risk restriction measures are always implemented in the energy sector. The probability of occurrence of $P(A)$ danger is determined during the operation of electrical installations in the presence of measures and means of protection: technical (protective grounding, fences, isolation of currentcarrying parts, automatic shutdown of electrical installations in emergency modes, etc.); organizational (work in accordance with the requirements specified in the orderadmission); appropriate personal protective equipment. The probability of occurrence of a certain type of danger (working under or near existing electrical installations, the influence of EMF, working at altitude, use of vehicles and power tools, etc.) is calculated by the duration of work during a certain billing period.

$$
P(A)=\frac{\tau_{i} \cdot K}{T_{y}},
$$

where $\tau_{i}$ is the duration of work in the presence of the $i$-th factor of danger, in accordance with the order-admission; $\mathrm{K}$ coefficient that determines the actual time of stay in the danger zone; $T_{y}$ is the estimated period taken at working hours during the year, i.e. $T_{y}$ equals 2080 hours.

These parameters were determined during experimental studies in 10-110-330 kV electrical installations of the Dniester Hydroelectric Power Plant.

A dangerous event can lead to an industrial accident. It is suggested that the probability of the impact of a dangerous event on an employee is determined by the statistical annual information on accidents by the formula:

$$
P(B)=\frac{n}{k \cdot N},
$$

where $n_{\mathrm{B} f}$ is the number of injured workers due to accidents caused by the $f$-th event; $k$ is the proportion of employees of an enterprise that may be affected by the $f$-th event during the year; $N$ is the total number of employees.

The probability of occurrence of $P_{d / f}$ consequences for an employee from a given adverse event in the presence of measures and equipment can be given as a product of probabilities - the severity of the consequences of $P(D)$ as a result of an accident and the limitation of the consequences of $P(C)$ through the introduction of new or additional equipment and measures [7] (personal protective equipment, additional isolation, improvement of professional skills through the latest teaching methods, etc.).

$$
P_{d / f}=P(D) \cdot P(C) \text {. }
$$

In assessing the risks of electro-technical workers as a consequence, we distinguish fatal (lethal) cases and accidents that have led to poor health of workers with temporary disability (injury, illness). The probability of fatalities is determined by the formula [6]:

$$
P(D)_{c}=\frac{n_{c}}{n_{0 f}}
$$

where $P(D)_{\mathrm{c}}$ is the probability of a fatal injury; $n_{c}$ - number of workers killed; $n_{0 f}$ is the number of employees affected by an accident caused by an $f$-event during the accounting period.

The probability of accidents leading to poor health

$$
P(D)_{t}=\frac{n_{t}}{n_{0 f}}
$$

where $P(D)_{t}$ is the probability of temporary disability; $n_{t}$ is the number of injured workers.

Thus, the individual risk of an employee in the presence of $f$ th adverse event is determined by the formula:

$$
R_{f}=P(A) \cdot P(B) \cdot P(C) \cdot P(D) .
$$

According to the above methodology, individual risks were calculated, which were adapted to the professional activity of electrical technicians (Table 2, 3).

The above calculations show that the total risk of electrotechnical workers at existing power supply companies is $4,84 \cdot 10^{-4}$, that is an average of five cases for every ten thousand employees, and the risk of injury or disability is $7,4210^{-3}$, that is, seven employees for every thousand employees. obviously, the proposed risk-based approach makes it possible to identify effective accident prevention measures in addition to stating the causes of injury. Introduction of the requirements of the EU Directives on safety of operation of electrical installations, reconstruction of overhead lines, improvement of electrical personal protection equipment, introduction of the latest training methods will allow to significantly reduce the level of injuries of electrical workers. 
TABLE II THE PROBABILITY OF EVENTS AND CONSEQUENCES ARISING FROM ACCIDENTS

\begin{tabular}{|c|c|c|c|c|}
\hline \multirow{2}{*}{$\begin{array}{c}\text { Adverse } \\
\text { event }\end{array}$} & \multicolumn{2}{|c|}{$\begin{array}{c}\text { The probability of } \\
\text { consequences } \boldsymbol{P}_{\text {d/f }}\end{array}$} & \multicolumn{2}{|c|}{ Individual risk } \\
\cline { 2 - 5 } & $\begin{array}{c}\text { The } \\
\text { probability } \\
\text { of a fatal } \\
\text { injury }\end{array}$ & $\begin{array}{c}\text { Probability } \\
\text { of } \\
\text { workability } \\
\text { loss }\end{array}$ & $\begin{array}{c}\text { The risk } \\
\text { of fatal } \\
\text { injury }\end{array}$ & $\begin{array}{c}\text { Risk of } \\
\text { workability } \\
\text { loss }\end{array}$ \\
\hline $\begin{array}{c}\text { Electric } \\
\text { current } \\
\text { injury }\end{array}$ & 0,32 & 0,68 & $1,72 \cdot 10^{-4}$ & $3,69 \cdot 10^{-4}$ \\
\hline $\begin{array}{c}\text { Injury at } \\
\text { motion }\end{array}$ & 0,17 & 0,83 & $1,14 \cdot 10^{-4}$ & $5,76 \cdot 10^{-4}$ \\
\hline $\begin{array}{c}\text { Falling } \\
\text { from a } \\
\text { height }\end{array}$ & 0,07 & 0,93 & $3,59 \cdot 10^{-5}$ & $4,64 \cdot 10^{-4}$ \\
\hline $\begin{array}{c}\text { Foreign } \\
\text { men's } \\
\text { injury }\end{array}$ & 0 & 1 & 0 & $2,67 \cdot 10^{-4}$ \\
\hline $\begin{array}{c}\text { EMF } \\
\text { irradiation }\end{array}$ & 0,06 & 0,94 & $1,62 \cdot 10^{-4}$ & $2,32 \cdot 10^{-3}$ \\
\hline $\begin{array}{c}\text { Increased } \\
\text { level of } \\
\text { work } \\
\text { difficulty }\end{array}$ & 0 & 1 & 0 & $2,12 \cdot 10^{-3}$ \\
\hline $\begin{array}{c}\text { Violation } \\
\text { of the } \\
\text { work } \\
\text { mode }\end{array}$ & 0 & 1 & 0 & $1,30 \cdot 10^{-3}$ \\
\hline
\end{tabular}

TABLE III THE PROBABILITY OF EVENTS AND CONSEQUENCES ARISING FROM ACCIDENTS

\begin{tabular}{|l|c|c|}
\hline \multicolumn{1}{|c|}{ Adverse event } & $\begin{array}{c}\text { The danger } \\
\text { probability }\end{array}$ & $\begin{array}{c}\text { The probability of a } \\
\text { hazard affecting an } \\
\text { employee }\end{array}$ \\
\hline $\begin{array}{l}\text { Electric current } \\
\text { injury }\end{array}$ & 0,15 & $3,62 \cdot 10^{-3}$ \\
\hline Injury at motion & 0,24 & $2,88 \cdot 10^{-3}$ \\
\hline $\begin{array}{l}\text { Falling from a } \\
\text { height }\end{array}$ & 0,21 & $2,51 \cdot 10^{-3}$ \\
\hline $\begin{array}{l}\text { Foreign men's } \\
\text { injury }\end{array}$ & 0,11 & $2,66 \cdot 10^{-3}$ \\
\hline EMF irradiation & 0,64 & $3,98 \cdot 10^{-3}$ \\
\hline $\begin{array}{l}\text { Increased level of } \\
\text { work difficulty }\end{array}$ & 0,52 & $4,25 \cdot 10^{-3}$ \\
\hline
\end{tabular}

\begin{tabular}{|l|l|l|}
\hline $\begin{array}{l}\text { Violation of the } \\
\text { work mode }\end{array}$ & 1,0 & $1,32 \cdot 10^{-3}$ \\
\hline
\end{tabular}

\section{CONCLUSIONS}

1. The analysis of working conditions showed that electrical workers are simultaneously affected by a number of dangerous and harmful production factors. It is established that now more than $22 \%$ of electrical workers work under the influence of one harmful factor, $30 \%$ - under the influence of two or more harmful factors, for $65 \%$ of working conditions in the workplace do not meet sanitary and hygienic standards. In 2018, there were 85 accidents involving 87 employees, seven of which were fatal.

2. The possibility of solving the problem of risk assessment for electro-technical workers by risk-oriented method using stochastic mathematical models is shown, which is correlated with the basic provisions of the European Parliament Directives. A methodology for calculating individual risk during the work is proposed, which makes it possible to further determine the effectiveness of the implementation of safety measures.

3. The results of the article are used in planning the sequence of measures to reduce the number of accidents when working at energy companies

\section{REFERENCES}

[1] A research and information certificate is about the level of traumatism on the power enterprises of Ukraine from 2010 to 2018 . Kyiv: NSRIISOSH, 2019.

[2] Technical rules of operation of power plants and networks, GKD 34.20.507. Kyiv, Haluzevyi rezervno-investytsiinyi fond rozvytku enerhetyky, 2003.

[3] Directive 2004/40/EC of the European Parliament and of the Council of 29 April 2004 on the minimum health and safety requirements regarding the exposure of workers to the risks arising from physical agents (electromagnetic fields), Strasburg, 2004.

[4] DSNiP 476-2002. State sanitary norms and rules are during work with the sources of the electromagnetic fields. Kyiv, Derzhstandart, 2002.

[5] Kasyanov, N. A., Gunchenko, O. N., Korennoy, V. I., Sabitova, O. A. \& Ulitina M.Yu. The development of assess method production risk in conducting rescue operation at construction sites. Construction, material science, mechanical engineering, 2016, 93, 56-65

[6] J.W. Vincoli. Basic guide to system safety. New York : Van Nostrand Reinhold, 1993.

[7] L. Tretiakova, L. Mitiuk "Methods of improvement of the system of defence of workers are from influence of the electromagnetic field of industrial frequency". Visnyk of NTUU "KPI" set "Mining", 2017, N 32, pp. 93-102.

[8] V. Opryshko Power supply mode control in the local microgrid system. Technical Electrodynamics. 2016, № 4, P.77-79. 